\title{
IbM-PENDAMPINGAN USAHA KERUPUK RUMAHAN DI DESA KEMBANG KABUPATEN PACITAN
}

\author{
Titik Wijayanti ${ }^{1)}$, Purwaning Budi Lestari ${ }^{2)}$ \\ ${ }^{1)}$ Prodi Pendidikan Biologi FPIEK IKIP Budi Utomo Malang \\ Email: kititn71@gmail.com \\ ${ }^{2)}$ Prodi Pendidikan Jasmani Kesehatan dan Rekreasi FPIEK IKIP Budi Utomo Malang \\ Email: purwaning.budilestari@gmail.com
}

\begin{abstract}
Abstrak
Guna meningkatkan kinerja usaha kerupuk rumahan di desa Kembang Kabupaten Pacitan, dilaksanakan program pengabdian berupa pendapingan bertajuk Iptek bagi Masyarakat. Dipilih dua mitra program IbM yang secara bersama menyusun rencana kerja, mendapatkan pelatihan produksi kerupuk dan menejemen usaha, mendapatkan bantuan peralatan, dan bantuan pendampingan pada proses produksi dan pemasaran. Program dilaksanakan mulai bulan Februari sampai dengan September 2017. Kedua varian kerupuk baru yang dihasilkan oleh kedua mitra program IbM memenuhi standar mutu gizi, mikrobiologis dan daya simpan yang baik serta mendapatkan respon positif dari konsumen. Kinerja usaha kedua produk kerupuk varian baru juga sangat baik dengan prosentase penjualan yang sangat tinggi, yakni lebih dari 90\%, jangka laku $100 \%$ yang singkat, yakni 1-2 hari dan tingkat pengembalian biaya produksi mencapai 1,5 kali. Program IbM dapat membuka jalan terhadap peningkatan keterampilan teknik produksi, peningkatan volum penjualan dan kinerja usaha, alternatif penjualan dalam bentuk kerupuk mentah, serta memberikan ide kreasi varian baru di masa mendatang.
\end{abstract}

Keywords: kerupuk ikan, kerupuk sayur, usaha rumahan, Pacitan

\section{PENDAHULUAN}

Dalam Rencana Pembangunan Jangka Menengah Nasional (RPJMN) 2015-2019, dijelaskan bahwa salah satu butir nawacita adalah membangun Indonesia dari pinggiran dengan memperkuat daerahdaerah dan desa dalam kerangka negara kesatuan. Selain itu dalam mencapai pertumbuhan ekonomi dan tingkat kemiskinan yang diupayakan terus menurun dan mencapai sekitar 7-8\% pada akhir tahun 2019 dan tingkat pengangguran terbuka menjadi $4-5 \%$ pada akhir tahun 2019, maka ditempuh langkah-langkah konkret. Salah satu upaya penting untuk meningkatkan kesejahteraan ekonomi masyarakat adalah pengembangan usaha kecil menengah yang dikelola oleh perorangan maupun kelompok dalam masyarakat.

Menurut Keputusan Presiden RI no. 99 tahun 1998 pengertian usaha kecil adalah kegiatan ekonomi rakyat yang berskala kecil dengan bidang usaha yang secara mayoritas merupakan usaha kecil dan perlu dilindungi untuk mencegah dari persaingan usaha yang tidak sehat. Kriteria usaha kecil menurut UU No. 9 tahun 1995, adalah (a) memiliki kekayaan bersih paling banyak Rp. 200.000.000 (dua ratus juta rupiah) tidak termasuk tanah dan bangunan tempat usaha; (b) memiliki hasil penjualan paling banyak Rp. 1.000.000.000 (satu miliar rupiah); (c) milik warna negara indonesia; (d) berdiri sendiri, bukan merupakan anak perusahaan atau cabang perusahaan yang tidak dimiliki, dikuasai atau berafiliasi baik langsung maupun tidak langsung dengan usaha menengah atau usaha besar; (e) berbentuk usaha orang perorangan, badan usaha yang tidak berbadan hukum atau badan usaha yang berbadan hukum, termasuk koperasi.

Di Indonesia, usaha kecil menengah (UKM) adalah tulang punggung ekonomi Indonesia. Jumlah UKM hingga 2011 mencapai sekitar 52 juta (http://economy.okezone.com). UKM di Indonesia sangat penting bagi ekonomi karena menyumbang $60 \%$ dari PDB dan menampung 97\% tenaga kerja (BPS, 2007). Salah satu pengembangan UKM adalah memberikan sentuhan teknologi terhadap proses produksi yang telah dirintis oleh suatu keluarga atau kelompok masyarakat. Sehingga kualitas produk yang dihasilkan menjadi lebih baik dan dapat meningkatkan nilai ekonomi dari produk yang dihasilkan dengan kemampuan faktor produksi yang ada.

Pacitan merupakan salah satu daerah di wilayah Jawa Timur dengan potensi sekaligus tantangan. Di Jawa Timur, Pacitan termasuk dari beberapa kabupaten/kota yang masih harus mengejar ketertinggalannya dengan daerah lain. Pada tahun 2016, pertumbuhan ekonomi Pacitan sempat melambat dari yang semula 5.21 persen pada tahun 
2015 manjadi 5,11 persen pada tahun 2016. Selain pelambatan ekonomi, Indeks Pembangunan manusia (IPM) serta kemiskinan capaiannya masih berada dibawah angka rata-rata provinsi. Saat ini, pertumbuhan ekonomi Pacitan masih ditopang oleh lapangan usaha sektor pertanian, kehutanan dan perikanan, yang mencapai 68,26 persen (https://pacitanku.com/2016/03/20/).

Sektor UKM di Kabupaten Pacitan juga perlu mendapatkan perhatian. Salah satu UKM di Kabupaten Pacitan adalah usaha produksi kerupuk rumahan. Beberapa usaha kerupuk rumahan di Pacitan berdiri sejak lama. Usaha rumahan kerupuk Pak Amat dan kerupuk Pak Yono merupakan salah satu contoh usaha yang terbentuk karena tuntutan kehidupan yaitu meningkatnya kebutuhan ekonomi keluarga. Kedua usaha kerupuk ini tepatnya berlokasi di Dusun Bubakan Desa Kembang Kabupaten Pacitan. Usaha rumahan kerupuk Pak Amat mulai dirintis sejak tahun 80an dan merupakan pelopor bagi usaha-usaha kerupuk lainnya di daerah setempat. Usaha kerupuk Pak Amat ini memiliki karyawan sebanyak 5 orang. Kelima orang karyawan tersebut adalah anggota keluarga sendiri yang terdiri dari satu isteri, dan 4 orang anak dari keluarga Pak Amat. Hal tersebut tidak jauh berbeda dengan usaha kerupuk milik Pak Yono. Usaha kerupuk Pak Yono memiliki 3 orang karyawan yang juga merupakan anggota keluarganya sendiri, ketiga orang karyawan tersebut adalah isteri Pak Yono dan 2 orang yang lain adalah anaknya. Sehingga usaha kerupuk ini bisa disebut dengan usaha keluarga (family business).

Meskipun telah berjalan hampir 30 tahunan usaha rumahan kerupuk Pak Amat dan Pak Yono tidak lantas berkembang menjadi sebuah perusahaan besar. Namun hingga saat ini usaha rumahan kerupuk Pak Amat dan Pak Yono masih tetap stagnan dan belum mengalami kemajuan yang berarti. Akan tetapi, meskipun dalam kondisi yang demikian usaha rumahan kerupuk Pak Amat dan Pak Yono tetap bertahan hingga sekarang. Hal tersebut diduga karena besarnya tuntutan ekonomi, dan tidak adanya keterampilan lain yang dimiliki oleh keluarga tersebut.

Kerupuk yang diproduksi oleh Pak Amat dan Pak Yono terbuat dari campuran bahan baku tepung terigu dan tapioka dengan perbandingan 3:1. Proses produksi kerupuk mulai membuat adonan, memasak kerupuk, mengiris, dijemur, dan digoreng) sendiri, kemudian dijual (dalam bentuk kemasan siap makan) sendiri pula. Kerupuk produksi Pak Amat dijual dan dipasarkan di pasar tradisional di pacitan, sedangkan produksi kerupuk Pak Yono dijual dan dipasarkan dibeberapa warung kopi dan depot makanan. Secara kemasan keduanya memiliki kesamaan, yaitu samasama dikemas dengan plastik dan menggunakan pengikat karet gelang. Hal ini menyebabkan tampilan kerupuk kurang menarik dan daya simpan kerupuk tidak tahan lama.

Melalui Program pengabdian kepada Masyarakat khususnya Iptek bagi Masyarakat (IbM) ini, penulis akan memberikan solusi dari permasalahan mitra dengan cara yaitu melakukan perbaikan mutu produksi kerupuk dari segi tampilan, rasa, kemasan serta nilai gizi kerupuk. Dari segi tampilan dapat dilakukan modifikasi bentuk kerupuk dari bentuk tak beraturan menjadi misalnya bentuk bulat, segitiga, segilima, ataupun persegi. Dari segi rasa dapat dilakukan diversifikasi jenis kerupuk dengan berbagai rasa seperti rasa pedas atau vegetarian. Perbaikan kemasan kerupuk bertujuan untuk meningkatkan daya simpan, dimana daya simpan berkolerasi dengan mutu kerupuk. Semakin lama umur simpan kerupuk maka akan melindungi dan menjaga mutu kualitas kerupuk tersebut. Untuk itu perbaikan kemasan lebih mengarah pada peningkatan daya simpan kerupuk. Sedangkan peningkatan nilai gizi kerupuk dapat dilakukan dengan cara substitusi bahan kerupuk, misalnya substitusi tepung terigu dengan tepung beras atau tepung mokaf, untuk peningkatan kandungan gizi protein dilakukan penambahan sumber protein seperti ikan (tuna, tengiri) dan udang. Untuk meningkatkan nilai gizi vitamin dapat dilakukan dengan penambahan sumber vitamin dari sayuran seperti seledri, kucai. Sedangkan untuk mengetahui kandungan nilai gizi pada kerupuk akan dilakukan pengujian nilai gizi secara laboratoris.

\section{METODE KEGIATAN}

Program pengabdian masyarakat Iptek bagi Masyarakat (IbM) ini dilaksanakan di lokasi usaha kedua mitra, yakni usaha kerupuk Pak Amat sebagai mitra 1 dan usaha kerupuk Pak Yono sebagai mitra 2. Tahapan yang dilakukan terlebih dahulu dengan melakukan kegiatan survey di tempat usaha kedua mitra yang berlokasi di dusun Bubakan desa Kembang kabupaten Pacitan guna mengetahui permasalahan mitra dan perencanaan solusi permasalahan yang dihadapi kedua mitra.

Tahapan pelaksanaan program Iptek bagi Masyarakat ini terdiri atas:

a. Diskusi rencana kerja, tahapan ini dilakukan perencanaan secara menyeluruh dan rinci tentang agenda kegiatan yang dilaksanakan selama program Iptek bagi Masyarakat 
berlangsung selama 8 bulan mulai bulan Februari sampai dengan September 2017.

b. Pelatihan produksi kerupuk, kegiatan meliputi pemberian materi teori dan praktek, dengan komposisi 30\% teori; $70 \%$ praktek yang meliputi materi pengenalan bahan, formulasi praktek produksi dan pengemasan.

c. Penyerahan peralatan produksi kerupuk, kegiatan yang ditujukan untuk meningkatkan kinerja produksi kerupuk varian baru kepada kedua produsen kerupuk rumahan yang menjadi mitra program IbM.

d. Pendampingan dan monitoring produksi serta pemasaran kerupuk varian baru oleh kedua produsen kerupuk rumahan yang menjadi mitra program IbM.

e. Pengujian kandungan gizi utama dan pelengkap produk kerupuk varian baru, yakni kerupuk ikan tuna dan kerupuk sayur di laboratorium kimia Universitas Muhammadiyah Malang

f. Uji respon konsumen terhadap kedua varian kerupuk baru yang dilaksanakan bersamaan dengan pemasaran kerupuk jenis ikan tuna dan kerupuk sayur.

g. Evaluasi dan Monitoring program secara keseluruhan untuk memberikan solusi terhadap permasalahan yang timbul selama program dan kesiapan kedua produsen kerupuk rumahan selepas program Iptek bagi Masyarakat (IbM) berakhir.

\section{HASIL DAN PEMBAHASAN}

Program pengabdian Iptek bagi Masyarakat berupa pendampingan usaha kerupuk rumahan dimulai dengan diskusi rencana kegiatan yang beragendakan penyusunan agenda kegiatan yang dilaksanakan selama program pendampingan. Kegiatan diskusi rencana kerja dilaksanakan pada bulan Februari, selama satu hari dan bertempat di rumah mitra 1. Pada kegiatan diskusi rencana kegiatan, melibatkan juga kedua mitra produsen kerupuk, sehingga diharapkan mendapatkan masukan dan umpan balik serta terjalin komunikasi yang baik.

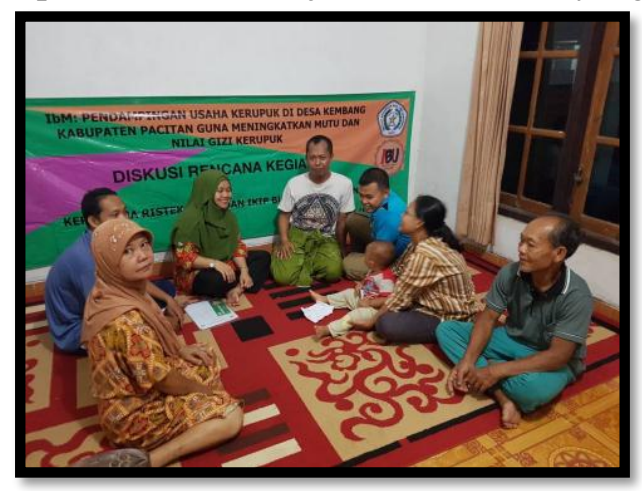

Gambar 1. Dokumentasi Diskusi Rencana Kegiatan Program IbM
Diskusi rencana kegiatan menghasilkan tahapantahapan pelaksanaan pendampingan yang meliputi pelatihan pembuatan kerupuk varian baru dan manajemen sederhana, bantuan peralatan usaha yang diperlukan serta pendampingan dan monitoring produksi dan penjualan produk kerupuk varian baru.

Tabel 1. Materi Pelatihan Produksi Kerupuk Varian Baru

\begin{tabular}{|c|c|c|c|}
\hline No & Materi & Waktu (pertemuan, @ 2 jam) & Keterangan \\
\hline 1. & Pengenalan Bahan & $\begin{array}{l}2 \text { pertemuan (kerupuk ikan tuna } \\
\text { dan kerupuk sayur) }\end{array}$ & $\begin{array}{l}\text { Pengenalan bahan-bahan } \\
\text { pembuatan, meliputi: sifat dan } \\
\text { teknik penanganan bahan }\end{array}$ \\
\hline 2. & Formulasi Bahan & $\begin{array}{l}2 \text { pertemuan (kerupuk ikan tuna } \\
\text { dan kerupuk sayur) }\end{array}$ & $\begin{array}{l}\text { Formulasi kerupuk ikan tuna dan } \\
\text { kerupuk sayur }\end{array}$ \\
\hline 3. & $\begin{array}{l}\text { Proses Produksi } \\
\text { (Teori) }\end{array}$ & $\begin{array}{l}2 \text { pertemuan (kerupuk ikan tuna } \\
\text { dan kerupuk sayur) }\end{array}$ & $\begin{array}{l}\text { Penjelasan teori tentang proses } \\
\text { produksi kerupuk ikan tuna dan } \\
\text { kerupuk sayur }\end{array}$ \\
\hline 4. & $\begin{array}{l}\text { Perhitungan formulasi } \\
\text { bahan (praktek) }\end{array}$ & $\begin{array}{l}2 \text { pertemuan (kerupuk ikan tuna } \\
\text { dan kerupuk sayur) }\end{array}$ & $\begin{array}{l}\text { Praktek perhitungan dan } \\
\text { penimbangan kebutuhan bahan } \\
\text { kerupuk ikan tuna dan kerupuk } \\
\text { sayur }\end{array}$ \\
\hline 5 . & $\begin{array}{l}\text { Pembuatan adonan } \\
\text { kerupuk (praktek) }\end{array}$ & $\begin{array}{l}2 \text { pertemuan (kerupuk ikan tuna } \\
\text { dan kerupuk sayur) }\end{array}$ & $\begin{array}{l}\text { Praktek pembuatan adonan kerupuk } \\
\text { ikan tuna dan kerupuk sayur }\end{array}$ \\
\hline 6. & $\begin{array}{l}\text { Pencetakan dan } \\
\text { Pengukusan adonan } \\
\text { kerupuk (praktek) } \\
\end{array}$ & $\begin{array}{l}2 \text { pertemuan (kerupuk ikan tuna } \\
\text { dan kerupuk sayur) }\end{array}$ & $\begin{array}{l}\text { Praktek pencetakan dan } \\
\text { pengukusan adonan kerupuk ikan } \\
\text { tuna dan kerupuk sayur }\end{array}$ \\
\hline 7. & $\begin{array}{l}\text { Pengirisan dan } \\
\text { pengeringan kerupuk } \\
\text { (praktek) }\end{array}$ & $\begin{array}{l}2 \text { pertemuan (kerupuk ikan tuna } \\
\text { dan kerupuk sayur) }\end{array}$ & $\begin{array}{l}\text { Praktek pengirisan dan pengeringan } \\
\text { kerupuk ikan tuna dan kerupuk } \\
\text { sayur }\end{array}$ \\
\hline 8. & $\begin{array}{l}\text { Penggorengan } \\
\text { kerupuk (praktek) }\end{array}$ & $\begin{array}{l}2 \text { pertemuan (kerupuk ikan tuna } \\
\text { dan kerupuk sayur) }\end{array}$ & $\begin{array}{l}\text { Praktek penggorengan kerupuk } \\
\text { ikan tuna dan kerupuk sayur }\end{array}$ \\
\hline 9. & $\begin{array}{l}\text { Pengemasan kerupuk } \\
\text { (praktek) }\end{array}$ & $\begin{array}{l}2 \text { pertemuan (kerupuk ikan tuna } \\
\text { dan kerupuls sayur) }\end{array}$ & $\begin{array}{l}\text { Praktek pengemasan kerupuk ikan } \\
\text { tuna dan kerupuk sayur }\end{array}$ \\
\hline 10. & $\begin{array}{l}\text { Manajemen usaha } \\
\text { singkat (Teori) }\end{array}$ & 1 pertemuan & $\begin{array}{l}\text { Penjelasan manajemen usaha dan } \\
\text { pengisian buku kas dan inventori }\end{array}$ \\
\hline
\end{tabular}

Tahap pelatihan dilaksanakan selama dua pekan pada bulan Maret berlokasi di rumah produsen kerupuk rumahan yang menjadi mitra pada program IbM. Pada tahap pelatihan terjadi umpan balik yang sangat baik yang memadukan pengalaman dari sisi produsen dan teori produksi yang baik. Sehingga menemukan titik temu pelaksanaan pada sisi praktis yang mudah bagi produsen kerupuk pada saat produksi kerupuk varian baru.

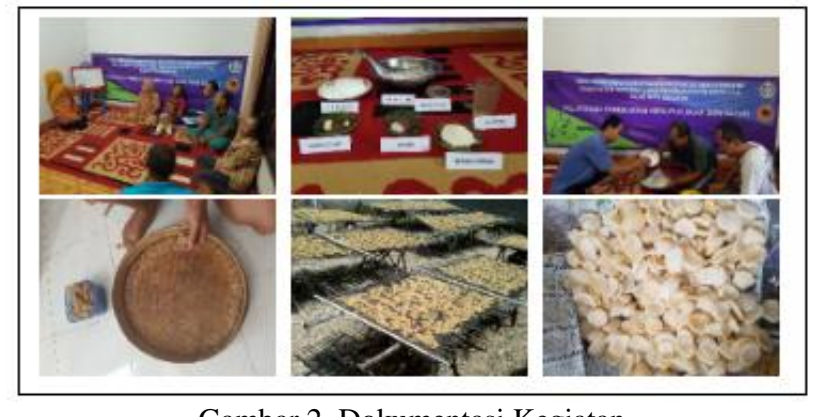

Gambar 2. Dokumentasi Kegiatan Pelatihan Produksi Kerupuk

Setelah tahap pelatihan produksi kerupuk varian baru, maka untuk memperlancar proses produksi kerupuk tersebut, dilakukan pemberian bantuan peralatan produksi yang diperlukan. Bantuan bersifat melengkapi peralatan yang telah dimiliki oleh pengusaha, yang dirasa kurang memadai. Bantuan yang diberikan kepada kedua mitra program IbM 
berupa wajan jedi bordes timbangan, sealer, dan plastik kemas kerupuk. Penyerahan bantuan peralatan produksi kerupuk dilakukan oleh Ketua RW Desa Kembang Kabupaten Pacitan yang bertempat di kediaman mitra 1.

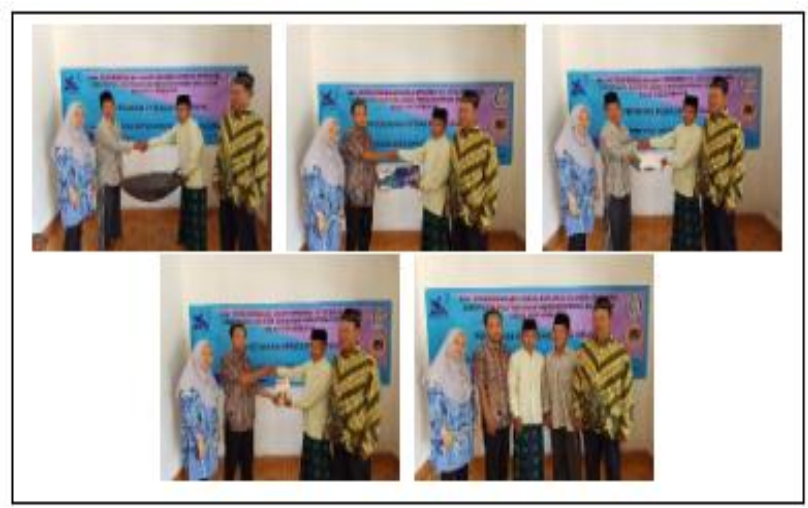

Gambar 3. Dokumentasi Penyerahan Bantuan Peralatan oleh Ketua RW Setempat

Setelah tahapan pelatihan dan penyerahan bantuan peralatan, maka kedua produsen kerupuk rumahan yang menjadi mitra program mulai memproduksi dan memasarkan produk kerupuk ikan tuna dan kerupuk sayur secara mandiri. Selama produksi dan pemasaran berlangsung, secara berkala dilakukan monitoring tahap produksi dan pemasaran dilaksanakan bulan Maret sampai dengan Agustus 2017.

Sejalan dengan dilaksanakannya proses produksi dan pemasaran produk kerupuk ikan tuna dan kerupuk sayur, dilakukan pengujian kualitas produk. Pengujian meliputi kualitas gizi, penampilan produk dan daya simpan. Kualitas gizi utama dan keamanan mikrobiologi yang diamati terdiri dari protein, lemak, air, abu, serat kasar, karbohidrat dan angka lempeng total (ALT). Selain itu juga dilakukan analisis kandungan gizi pelengkap, yang meliputi kandungan vitamin dan komposisi asam lemak pada kedua produk. Sedangkan penampilan produk dilakukan secara organoleptik yang terdiri dari warna, kerenyahan, rasa, dan aroma produk. Untuk uji daya simpan, dilakukan penyimpanan kerupuk dalam kemasan sampai produk tidak layak konsumsi (melempem atau tengik). Pengujian kualitas gizi dan keamanan mikrobiologi dan organoleptik dilakukan pada kondisi kerupuk mentah, matang dan kondisi tidak layak konsumsi. Pelaksanaan pengujian kualitas gizi dan ALT dilakukan di Laboratorium Kimia Universitas Muhammadiyah Malang. Pengujian secara organoleptik terhadap warna, kerenyahan, rasa dan aroma dilakukan oleh konsumen kerupuk pada produk kerupuk mentah, matang dan tidak layak konsumsi. Uji daya simpan dilakukan pada produk kerupuk yang sudah dikemas dengan plastik kemas yang digunakan pada saat pemasaran kerupuk dan diamati tiap hari untuk ditentukan jumlah hari sampai produk kerupuk tersebut tidak layak konsumsi yang meliputi melempem dan tengik. Komposisi kualitas gizi utama (proksimat) dan kualitas mikrobiologis kedua produk kerupuk varian baru pada saat kondisi mentah, matang dan tidak layak konsumsi tersaji pada tabel 2

Tabel 2. Komposisi Gizi Kedua Varian Kerupuk pada Berbagai Kondisi

\begin{tabular}{lcccccc}
\hline \multirow{2}{*}{ Parameter - Satuan } & \multicolumn{2}{c}{ Mentah } & \multicolumn{2}{c}{ Matang } & \multicolumn{2}{c}{$\begin{array}{c}\text { Tidak layak } \\
\text { konsumsi }\end{array}$} \\
\cline { 2 - 8 } & Ikan & Sayur & Ikan & Sayur & Ikan & Sayur \\
\hline Protein $(\mathrm{g} / 100 \mathrm{~g})$ & 17,27 & 12,82 & 12,86 & 8,12 & 9,14 & 4,11 \\
\hline Lemak $(\mathrm{g} / 100 \mathrm{~g})$ & 3,08 & 1,52 & 14,26 & 12,89 & 20,94 & 17,57 \\
\hline Air $(\mathrm{g} / 100 \mathrm{~g})$ & 11,54 & 12,07 & 0,13 & 0,17 & 5,87 & 8,36 \\
\hline Abu $(\mathrm{g} / 100 \mathrm{~g})$ & 0,18 & 0,06 & 0,15 & 0,03 & 0,15 & 0,03 \\
\hline Serat kasar $(\mathrm{g} / 100 \mathrm{~g})$ & 0,12 & 0,43 & 0,08 & 0,027 & 0,08 & 0,027 \\
\hline Karbohidrat $(\mathrm{g} / 100 \mathrm{~g})$ & 67,93 & 73,53 & 72,6 & 78,79 & 63,9 & 69,93 \\
\hline $\begin{array}{l}\text { Angka Lempeng Total } \\
\text { (kol/g) }\end{array}$ & 85 & 62 & 7 & 4 & 143 & 107 \\
\hline Daya simpan (hari) & & & & & 25 & 28 \\
\hline
\end{tabular}

Tabel 2 menunjukkan bahwa kualitas kerupuk yang diproduksi, baik kerupuk ikan tuna dan kerupuk sayur bawang pre memiliki kualitas gizi dan keamanan pangan yang cukup baik. Standar kualitas yang digunakan sebagai acuan adalah SNI 8272: 2016 tentang kerupuk ikan, udang dan moluska. Hasil pengujian kadar vitamin kedua kerupuk juga menunjukkan kandungan vitamin yang beragam dengan kadar yang cukup baik, terutama pada produk kerupuk sayur. Vitamin yang terkandung adalah vitamin A, B1, B2, B3, B5, B6, B7, B9, B12, C, dan E. Kedua jenis kerupuk juga mengandung asam lemak yang cukup baik, terutama pada kerupuk ikan tuna yang mempunyai kelebihan adanya asam lemak omega 3 yakni: alpha linolenic acid (ALA), eicosapentaenoic acid (EPA) dan docosahexaenoic acid (DHA) dan asam lemak omega 6, linoleic acid (LA).

Sedangkan daya simpan kedua varian kerupuk cukup baik, yaitu 25 hari untuk kerupuk ikan tuna dan 28 hari untuk kerupuk sayur. Pada saat kerupuk dinyatakan tidak layak konsumsi karena keadaan melempem dan tengik, terjadi perubahan kualitas nilai gizi pada kedua varian kerupuk. Perubahan yang terjadi adalah penurunan komponen protein, kenaikan komponen lemak dan air, serta angka lempeng total. Sedangkan pada komponen kadar abu dan karbohidrat tidak mengalami perubahan. Daya simpan yang cukup baik, dikarenakan adanya 
perbaikan pada teknik penyegelan (sealing) kemasan dengan menggunakan sealer listrik dan penggunaan plastik yang lebih baik, namun tidak terlalu membebani ongkos produksi.

Data kualitas produk kerupuk tersebut menunjukkan bahwa secara umum, produk yang dihasilkan sudah memenuhi standar yang digunakan. Sehingga produk yang ditawarkan kepada konsumen mempunyai nilai gizi yang baik dan keamanan pangan yang terjamin. Seperti diketahui, kerupuk mreupakan jenis kudapan yang digunakan sebagai pendamping makan atau kadang hanya sekedar camilan. Pada masyarakat yang miskin, terkadang kerupuk merupakan lauk untuk makan bersama nasi atau nasi tiwul.

Dengan kualitas gizi kerupuk yang dikonsumsi cukup baik, maka cukup dapat membantu asupan gizi pada berbagai lapisan masyarakat. Dengan keamanan mikrobiologi yang terjamin, maka memberikan rasa aman dalam mengkonsumsi suatu produk makanan, khususnya kerupuk. Dengan daya simpan yang cukup panjang, memberi waktu untuk pemasaran dan menghindari kerugian akibat kerusakan produk, serta memberi jaminan kualitas produk kerupuk bagi masyarakat. Jaminan produk kerupuk bagi konsumen merupakan poin penting dalam faktor pemasaran suatu produk kerupuk.

Suatu produk yang baik tidak ada gunanya, jika penilaian konsumen tidak sesuai harapan. Demikian juga pada produk kerupuk baru yang dibuat, dilakukan uji respon konsumen secara organoleptik terhadap produk kerupuk kedua produsen kerupuk rumahan tersebut. Hasil penilaian organoleptik kedua varian kerupuk baru pada berbagai kondisi disajikan pada tabel 3.

Tabel 3. Respon Konsumen Secara Organoleptik Kedua Varian Kerupuk Berbagai Kondisi

\begin{tabular}{lcccccc}
\hline \multirow{2}{*}{$\begin{array}{c}\text { Parameter } \\
\text { Organoleptik }\end{array}$} & \multicolumn{2}{c}{ Mentah } & \multicolumn{2}{c}{ Matang } & \multicolumn{2}{c}{$\begin{array}{c}\text { Tidak layak } \\
\text { konsumsi }\end{array}$} \\
\cline { 2 - 8 } & Ikan & Sayur & Ikan & Sayur & Ikan & Sayur \\
\hline Warna & 3,48 & 3,61 & 3,53 & 3,69 & 2,14 & 2,19 \\
\hline Kerenyahan & $*$ & $*$ & 3,75 & 3,29 & 1,03 & 1,06 \\
\hline Rasa & $*$ & $*$ & 3,19 & 2,95 & 1,87 & 1,93 \\
\hline Aroma & 3,21 & 3,38 & 3,38 & 3,57 & 1,18 & 1,32 \\
\hline
\end{tabular}

Keterangan: * tidak dilakukan pengujian

Tabel 3 menunjukkan bahwa pada kondisi mentah, kedua varian diberi skala kesukaan yang cukup baik pada parameter warna dan aroma. Secara umum kedua varian kerupuk dinilai pada skala suka sampai sangat suka. Pada kondisi matang pun demikian, pada semua parameter organoleptik yang meliputi warna, kerenyahan, rasa dan aroma, nilai skala bernilai suka sampai sangat suka pada kedua varian kerupuk. Pada kondisi kerupuk tidak layak konsumsi, terjadi penurunan skala kesukaan pada kedua varian, pada semua parameter organoleptik, kedua varian kerupuk bernilai skala kesukaan tidak suka sampai cukup suka.

Hasil uji respon konsumen menunjukkan bahwa potensi kedua varian kerupuk untuk dijual dalam keadaan mentah cukup baik. Sehingga tentu saja, akan menambah variasi penjualan kedua produsen kerupuk rumahan yang biasanya hanya menjual produk kerupuk matang. Responden yang merupakan konsumen kerupuk juga memberikan penilaian yang baik pada produk kerupuk matang sehingga potensi peningkatan penjualan pada kedua varian kerupuk baru juga cukup terbuka lebar. Uji respon konsumen pada saat kerupuk tidak layak konsumsi untuk mengukur tingkat kesukaan ketika memperoleh produk yang kurang baik. Hal ini memberikan informasi yang baik bagi produsen untuk segera mengganti atau meningkatkan pemasaran sehingga punya cukup banyak waktu pemasaran.

Pada tahap produksi dan pemasaran, kedua produsen menunjukkan kinerja usaha yang cukup baik. Resume kinerja usaha kedua produsen dalam produksi dan pemasaran produk kerupuk ikan tuna dan sayur tersaji pada tabel 4 .

Tabel 4. Tabel kinerja usaha kedua mitra program IbM

\begin{tabular}{clcccc}
\hline \multirow{2}{*}{ No } & \multicolumn{2}{c}{ Penilaian Kinerja } & \multicolumn{2}{c}{ Mitra 1 } & \multicolumn{2}{c}{ Mitra 2 } \\
\cline { 3 - 6 } & Ikan tuna & Sayur & Ikan tuna & Sayur \\
\hline 1 & $\begin{array}{l}\text { Jumlah produksi per hari } \\
\text { (bungkus) }\end{array}$ & 500 & 500 & 500 & 500 \\
\hline 2 & $\begin{array}{l}\text { Jumlah yang terjual per hari } \\
\text { (bungkus) }\end{array}$ & 480 & 479 & 490 & 487 \\
\hline 3 & Prosentase produk terjual (\%) & 96 & 95,8 & 98 & 97,4 \\
\hline 3 & Harga (Rp/bungkus) & 500 & 500 & 500 & 500 \\
\hline 4 & Pendapatan per hari (Rp/hari) & 240.000 & 239.500 & 245.000 & 243.500 \\
\hline 5 & Biaya produksi (Rp/bungkus) & 200 & 200 & 200 & 200 \\
\hline 6 & $\begin{array}{l}\text { Biaya produksi per hari } \\
\text { (Rp/hari) }\end{array}$ & 100.000 & 100.000 & 100.000 & 100.000 \\
\hline 7 & Keuntungan per hari (Rp/hari) & 140.000 & 139.500 & 145.000 & 143.500 \\
\hline 8 & $\begin{array}{l}\text { Tingkat keuntungan dibanding } \\
\text { biaya produksi }\end{array}$ & 1,4 & 1,395 & 1,45 & 1,435 \\
\hline
\end{tabular}

Keterangan: data kinerja 2 bulan pertama pendampingan

Tabel 4 menunjukkan bahwa prosentase produk yang terjual pada kedua mitra IbM sangat tinggi pada dua bulan pertama penjualan, yakni diatas $90 \%$. Hal tersebut menunjukkan respon konsumen yang sangat tinggi terhadap produk kerupuk baru dengan rasa yang baru dengan harga yang terjangkau. Berdasarkan data penjualan juga menunjukkan bahwa untuk mencapai $100 \%$ penjualan produk, tidak membutuhkan waktu terlalu lama, hanya 1-2 hari. Tabel 4 juga menunjukkan bahwa tingkat keuntungan berbanding biaya produksi cukup tinggi, yaitu 1,3-1,5 
yang berarti sebanyak 1,5 kali biaya yang dikeluarkan sebagai biaya produksi kembali.

Respon konsumen terhadap produk kerupuk mentah juga cukup baik, sehingga patut dipertimbangkan untuk melakukan penjualan dalam bentuk produk mentah. Tentu saja harus dikaji sasaran penjualan yang tepat. Sasaran penjualan untuk produk mentah adalah toko-toko atau kepada orang-orang yang berminat untuk berwirausaha kerupuk dengan membeli produk mentah untuk digoreng dan dipasarkan sendiri. Sehingga dengan demikian dapat menarik perorangan atau kelompok masyarakat lain yang belum mandiri untuk berusahan.

\section{KESIMPULAN}

Berdasarkan uraian di atas maka dapat ditarik kesimpulan sebagai berikut:

a. Kualitas kerupuk yang diproduksi (kerupuk ikan tuna dan kerupuk sayur) memiliki kualitas gizi dan keamanan pangan yang cukup baik sesuai acuan standar SNI 8272: 2016 tentang kerupuk ikan, udang dan moluska.

b. Daya simpan kedua kerupuk cukup baik, yaitu 25 hari untuk kerupuk ikan tuna dan 28 hari untuk kerupuk sayur.

c. Respon konsumen sangat tinggi terhadap produk kerupuk varian baru, dengan rasa yang baru dan harga yang terjangkau, hal ini ditunjukkan dengan prosentase penjualan produk yang mencapai lebih dari $90 \%$ pada dua bulan pertama dan hal ini cukup menguntungkan bagi mitra.

d. Respon konsumen terhadap produk kerupuk mentah juga cukup baik sehingga patut dipertimbangkan untuk melakukan penjualan dalam bentuk produk mentah dengan sasaran penjualan yang tepat.

\section{REFERENSI}

AOAC, 1998. the Official Methods of Analysis of AOAC INTERNATIONAL. Association Official Analitycal Communities

BPS, 2007. Pengukuran dan Analisis Ekonomi Kinerja Penyerapan Tenaga Kerja, Nilai Tambah UKM Serta Peranannya Menurut Harga Konstan dan Berlaku Tahun 2007. BPS dengan Program Peningkatan Kualitas Pelayanan Publik Kantor Menteri Negara KPKM

Badan Standarisasi Nasional, 2016. SNI 8272:2016 Kerupuk ikan, udang dan moluska. Jakarta

http://economy.okezone.com/read/2011/07/27/320/4 84884/ukm-jangan-ditarik-pajak

https://pacitanku.com/2016/03/20/pertumbuhanekonomi-pacitan-melambat/

Keputusan Presiden RI No. 99 Tahun 1998 Tentang Bidang/Jenis Usaha Yang Dicadangkan Untuk Usaha Kecil dan Bidang/Jenis Usaha Yang Terbuka Untuk Usaha Menengah atau Usaha Besar Dengan Syarat Kemitraan. Presiden RI

Kementrian Perencanaan Pembangunan Nasional/Badan Perencanaan Pembangunan Nasional, 2014. Peraturan Presiden RI No. 2 Tahun 2015 Tentang Rencana Pembagunan Jangka Menengah Nasional 2015-2019

Putri, K. 2014. Perkembangan Perindustrian Di Indonesia Dari Tahun Ke Tahun. Wordpress.com

Undang-Undang Republik Indonesia No. 9 Tahun 1995 Tentang Usaha Kecil. Presiden R 